\title{
Factors Influencing Soil and Water Conservation Adoption in Basheri, Gheshnashm and Shmangus Laelai, Eritrea
}

\author{
Tumuzghi Tesfay ${ }^{1}$, Woldeselassie Ogbazghi ${ }^{2}$, Balwan Singh ${ }^{3 \#}$, Tesfai Tsegai $^{4}$ \\ 1, 2, 3 Department of Land Resources and Environment, Hamelmalo Agricultural College, P.O. Box 397. \\ Keren, Eritrea. \\ ${ }^{4}$ Department of Agricultural Economics, Hamelmalo Agricultural College, P.O. Box 397, Keren, Eritrea.
}

\#corresponding author.

Type of Review: Peer Reviewed.

DOl: http://dx.doi.org/10.21013/jas.v12.n2.p1

\section{How to cite this paper:}

Tesfay, T., Ogbazghi, W., Singh, B., Tsegai, T. (2018). Factors Influencing Soil and Water Conservation Adoption in Basheri, Gheshnashm and Shmangus Laelai, Eritrea. IRA International Journal of Applied Sciences (ISSN 2455-4499), 12(2), 7-14. doi.http://dx.doi.org/10.21013/jas.v12.n2.p1

(C) Institute of Research Advances.

\section{(cc) EY-NC}

This work is licensed under a Creative Commons Attribution-Non Commercial 4.0 International License subject to proper citation to the publication source of the work.

Disclaimer: The scholarly papers as reviewed and published by the Institute of Research Advances (IRA) are the views and opinions of their respective authors and are not the views or opinions of the IRA. The IRA disclaims of any harm or loss caused due to the published content to any party.

Institute of Research Advances is an institutional publisher member of Publishers International Linking Association Inc. (PILA-CrossRef), USA. The institute is an institutional signatory to the Budapest Open Access Initiative. Hungary advocating the open access of scientific and scholarly knowledge. The Institute is a registered content provider under Open Access Initiative Protocol for Metadata Harvesting (OAI-PMH).

The journal is indexed \& included in CAS Source Index of Chemical Abstracts Service of American Chemical Society (USA), Index Copernicus (IC Value 85.27), WorldCat Discovery Service (USA), CrossRef Metadata Search (USA), WorldCat (USA), OCLC (USA), Open J-Gate (India), EZB (Germany) Scilit (Switzerland), Airiti (China), Bielefeld Academic Search Engine (BASE) of Bielefeld University, Germany, PKP Index of Simon Fraser University, Canada. 


\begin{abstract}
In response to widespread land degradation remarkable Soil and Water Conservation (SWC) interventions were carried out in Eritrea. Nonetheless, such interventions were not adopted by farmers and the problem still persists, hence this research was carried out from June 2015 to June 2016 to identify the factors affecting the SWC practices in Eritrea. Seventy two farm household heads were selected through quota simple random sampling and data was collected through group discussions, pair-wise problem ranking, participatory transect walks and semi-structured household questionnaire surveys. Descriptive statistics and binary logistic regression model were used for data analysis. The results indicated that only $23.61 \%$ of the respondents practice proper SWC in their farms. Moreover, the logistic regression analysis revealed that off-farm activities, land tenure insecurity, educational level of household head and household head being female had significant negative effects on SWC efforts, whereas slope of the farm showed significant positive effect. Land tenure insecurity, weak extension service and low agricultural production were also ranked by farmers as the first three constraints in SWC practices. As the legacy of the past food for work and cash for work programs, SWC is considered as a paid-work by local communities. Hence, appropriate agricultural extension, land tenure security and introduction of agro-forestry farming systems are recommended in the study area.
\end{abstract}

Key words: Binary logistic model, Eritrea, Hamelmalo, SWC interventions, tenure insecurity

\title{
Introduction
}

SWC has a long history in Eritrea; people have been farming for thousands of years and in parallel to that traditional conservation methods have evolved at the local level; in addition to the traditional SWC practices, during the Italian colonial period some SWC interventions including tree planting were promoted in agricultural experimental sites and near settlements, from 1922 to 1932, 1.2 million tree seedlings were planted in Eritrea [2]. Historical and archaeological evidences suggest that the Eritrean farming communities have practiced SWC for a very long period. The Safira micro-dam is a vivid witness. The magnificent soil bunds and grass strips, locally called 'Deret' literally meaning bunds, indicate that SWC practices are not new to Eritrea [20]. Between 1979 and 1992, about US\$ 116 million of food for work assistance was allocated exclusively for SWC works in Eritrea [3]. Since independence of Eritrea in 1991, through community campaigns, students summer works, national service campaigns, institutions and individuals; remarkable SWC works including hillside terracing, soil and stone bunding, tree planting, enclosures establishment, check dam and micro-dam constructions have been undertaken so as to rehabilitate degraded lands and increase the resilience of ecosystems [2,11]. From 1992 to $2014,56,054$ ha of hillsides were terraced; $7,306,745 \mathrm{~m}^{3}$ of check dams, 40,182 $\mathrm{km}$ of stone bunds and $46,709 \mathrm{~km}$ soil bunds were constructed. Reforestation has been also a major activity of the ministry of agriculture (MoA) involving both appreciable expense and labour. This has been intensified in the recent years; for instance in 2014 alone 3,628,804 tree seedlings were planted covering 1,597 ha of land with survival rate of $81 \%$. During the same period 214,133 ha of temporary enclosures and 94,099 ha of permanent enclosures were established [20]. Despite the intended outcomes of mitigating land degradation, many of these interventions weren't adopted and maintained by farmers, many of the structures and plantations were destroyed right after the completion of projects [11]. Thus, the current study was initiated to thoroughly identify and describe the underlying causes so as to fill the information gap and contribute to the country's efforts in combating land degradation.

\section{Materials and Methods}

\section{Description of the study sites}

Basheri: Basheri village is located in zoba Anseba, sub-zoba Hamelmalo along the Keren-Nakfa road; $13 \mathrm{Km}$ north of the Keren town. The area belongs to the arid lowlands agro ecological zone (AEZ) of Eritrea having an average annual rainfall of $414.13 \mathrm{~mm}$ (average past 15 years), potential evapotranspiration rate of $1800-2000$ $\mathrm{mm} /$ year [12] and average annual temperature of $25^{\circ} \mathrm{C}$; with the highest mean monthly temperature of $36.2^{0} \mathrm{C}$ in May and the lowest $11.0^{\circ} \mathrm{C}$ in January [19]. Basheri village has 215 households with a total population of around 1500. Subsistence mixed farming, crop and livestock, is the main stay of the households. Sorghum, pearl millet and groundnut are the common crops grown under rainfed conditions and goats, sheep, cattle, donkeys and camels are the livestock reared in the area. Crop yields, on an average, were less than $0.7 \mathrm{t} / \mathrm{ha}$, consequently farmers were poor. The growing season (moist period) starts in the last week of June and ends in the second week of September.

Gheshnashm and Shmangus Laelai: Shmangus Laelai and Gheshnashm villages are located in zoba Maekel, sub-zoba Serejeka along the Asmara-Keren road; the former $22 \mathrm{~km}$ and the latter $28 \mathrm{~km}$ northwest of Asmara. 
These villages are located in the moist highlands AEZ of Eritrea. Records from Afdeyu, a nearby SWC research station, showed that from 1985 to 2015 the maximum and minimum annual rainfalls were $722.1 \mathrm{~mm}$ in 2010 and $199.8 \mathrm{~mm}$ in 1990, respectively. Over the same period, the average annual rainfall was $501.6 \mathrm{~mm}$ and the average monthly maximum and minimum temperatures were $22.80^{\circ} \mathrm{C}$ and $11.12^{\circ} \mathrm{C}$, respectively. Gheshnashm and Shmangus Laelai had 240 and 260 households, respectively. Subsistence mixed farming system, crop and livestock, is the main stay of the households. Barley, wheat, cowpea and potato are the main crops under rainfed conditions and goats, sheep, cattle and donkey are the livestock in these areas. The growing season (moist period) starts in the last week of June and ends in the first week of September.

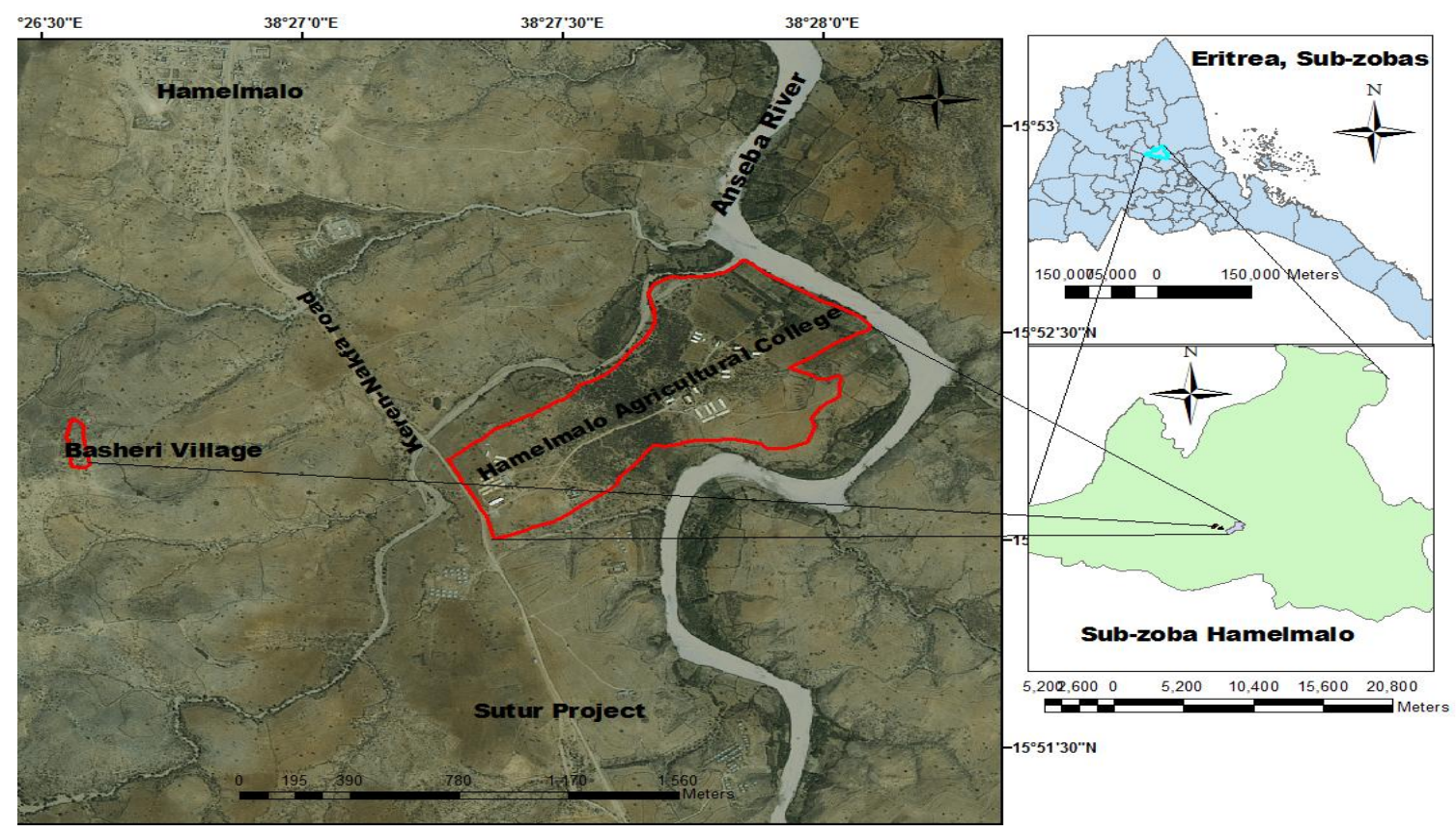

Figure 1 Location of Basheri village

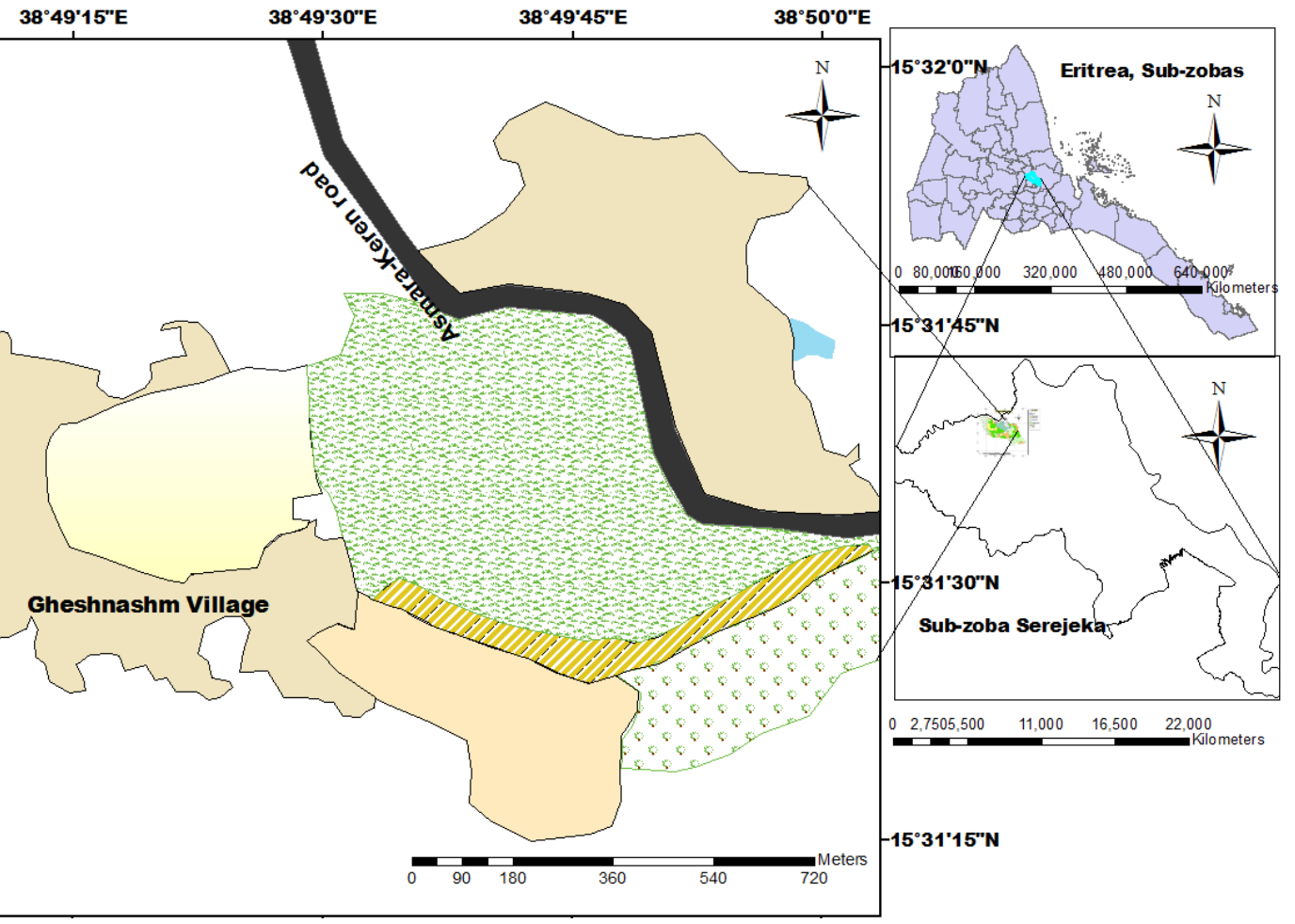

Figure 2 Location of Gheshnashm village 


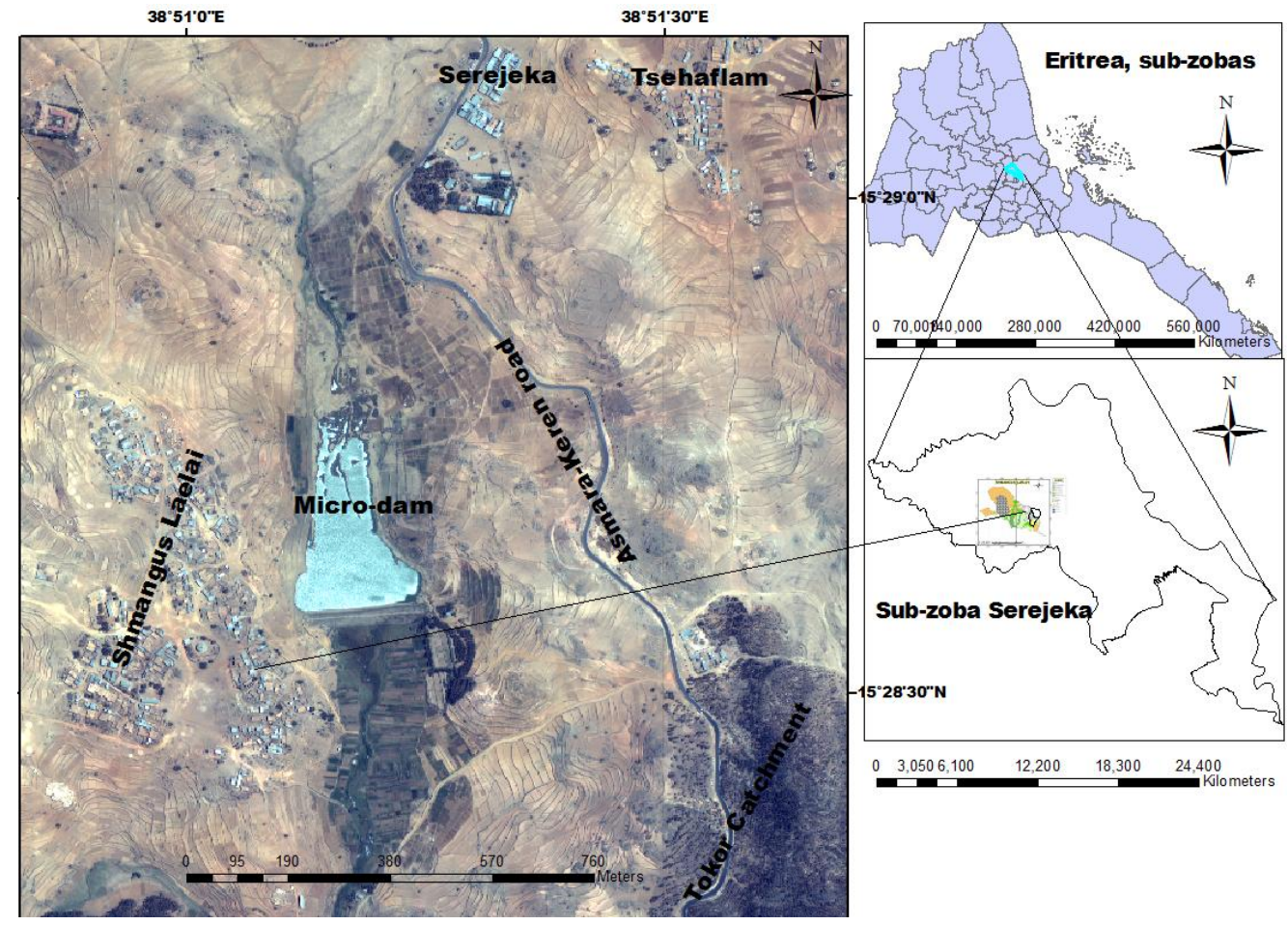

Figure 3 location of Shmangus Laelai village

\section{Data collection and analysis}

Participatory rural appraisal (PRA): PRA was used in order to help the local communities to investigate, analyse and prioritise existing problems related to SWC and seek appropriate solutions to the problems. Similar methodologies were used by different scientists [6,18]. $10 \%$ of the households were selected from each study village by quota simple random sampling method from sampling frame of separate name lists of male and female household heads. 22, 24 and 26 representative household heads were selected from Basheri, Gheshnashm and Shmangus Laelai villages, respectively.

Criteria for measuring SWC effort of a household: Criteria for measuring SWC technology adoption level of farming households may differ from project to project. But in general, an exemplary farmer is expected to apply the recommended SWC measure in his farmland, monitor it closely and maintain if it needs so and further enhance the fertility of his farmland. Considering the fact that the SWC interventions in the study areas were not full SWC packages and there were not specific SWC measures recommended, except the general objective of land rehabilitation and production increase, most of the interventions were small scale and fragmented. Thus, criteria for measuring the threshold SWC effort of a household was decided through farmers group discussions as follows:

1. First, there should be SWC measures in a household's farmland/s; whatever the SWC measure was. In case of Gheshnashm and Shmangus Laelai, since each household had 5 small and fragmented farm plots, there should be SWC structures in all the 5 fragmented fields. In case of Basheri, as the farmland of a household was in one place only, all of the farmland was expected to have SWC measures, which could be implemented by the household, mass campaign, projects etc.

2. A household was also expected to closely monitor and maintain the SWC structures. Considering the open and heavy grazing within the study areas, all SWC structures need close checkup and maintenance at least once a year.

3. Furthermore a household was expected to enhance the fertility of its farmland; at least it has to replenish the nutrients removed by crop harvest (grain + aboveground biomass) each year. This could be done by manure and/or fertilizer application or other means.

4. A SWC effort was also expected to enhance crop production, improve food self-sufficiency, nutrition and all the living condition of a household. Thus, food self-sufficiency was also included as a requirement for the threshold SWC effort; at least a household should secure its annual food demand from its farmland.

Furthermore the participatory transect walks were planned to cover almost all the farmlands so that the adequacy and condition of SWC structures of the mentioned hard working farmers could be observed and discussed. Condition of soil erosion of a conserved farmland was taken to measure the adequacy of SWC structures for that specific field. 
Each hardworking farmer, who passed the threshold level of SWC effort, gave the manure/fertilizer he/she applied each year in $\mathrm{kg} / \mathrm{ha} /$ year, crop production in $\mathrm{kg} / \mathrm{ha}$, level of household income in Nakfa, improvements in household food security and household living condition in general were in scale of 1-5. This was cross checked with the household questionnaire results which were filled later on.

Binary logistic model: Farmers have accumulated knowledge of their local conditions and especially their farmlands. Farmers know what can be done to improve productivity of their farmlands but failed to do so due to different reasons [20]. In this study, the adoption of SWC practices was assumed to depend upon a set of attributes that apply to a plot of land, some of which were specific to the particular region, the village, the farm or the plot within the farm. Thus, after a thorough literature review [4,8,9,13,14,15 and 17], farmers group discussions, pair wise problems ranking, formal and informal interviews and participatory transect walks; independent variables that were expected to affect the SWC effort of a household in particular to the study sites were hypothesised (Table 1). By and large, these variables were based on the local farmers' knowledge and experiences.

A logistic regression model that reflects the observed status of SWC effort on farmlands was selected for the reason that such observations reflect dichotomous variable, adoption or non-adoption of SWC technologies. Following [10], the logistic regression model characterizing adoption by the sample households was specified as;

$\mathrm{P}_{\mathrm{i}}=\mathrm{f}\left(\alpha+\beta \mathrm{X}_{\mathrm{i}}\right)=1 /\left[1+\mathrm{e}^{-(\alpha+\beta \mathrm{Xi})}\right]$

Where, subscript $i$ denotes the $\mathrm{i}^{\text {th }}$ observation in the sample, $\mathrm{P}$ is the probability that an individual will make a certain choice for given $\mathrm{X}_{\mathrm{i}}$ e is the base of natural logarithms, $\mathrm{Xi}$ is a vector of exogenous variables, $\alpha$ and $\beta$ are parameters of the model, $\left(\beta_{1}, \beta_{2}, \ldots \ldots, \beta_{\mathrm{k}}\right)$ are the coefficients associated with each explanatory variables $\left(\mathrm{X}_{1}\right.$, $\left.\mathrm{X}_{2}, \ldots, \mathrm{X}_{\mathrm{n}}\right)$

The above function can be rewritten as:

$\mathrm{li}=\ln [\mathrm{Pi} /(1-\mathrm{Pi})]=\beta \mathrm{o}+\beta_{1} \mathrm{X}_{1 \mathrm{i}}+\beta_{2} \mathrm{X}_{2 \mathrm{i}}+\ldots \ldots \ldots+\beta_{\mathrm{k}} \mathrm{X}_{\mathrm{ni}}+\mathrm{e}_{\mathrm{i}}$

Where: $\mathrm{e}$ is a disturbance term and the parameters $\beta$ are estimated using maximum likelihood techniques.

Specifically, the empirical model is specified as:

SWC $_{\mathrm{i}}=\beta_{0}+\beta_{1}$ GENDER $_{\mathrm{i}}+\beta_{2}$ AGE $_{\mathrm{i}}+\beta_{3}$ EDUCATION $_{\mathrm{i}}+\beta_{4}$ SOCIAL $_{\mathrm{i}}+\beta_{5}$ FAMILYSIZE $_{\mathrm{i}}+\beta_{6}$ AGRILABOR $_{\mathrm{i}}+$ $\beta_{7}$ SLOPE $_{i}+\beta_{8}$ OFFFARM $_{i}+\beta_{9}$ TENUREIN $_{i}+\beta_{10}$ TRAINING $_{i}+\beta_{11}$ LIVESTOCK $_{i}+e_{i}$

Where: $\beta_{0}$ is the constant term, $\beta_{1}$ to $\beta_{11}$ are unknown parameters to be estimated, e is the disturbance term.

Table 1: Independent variables that were hypothesized to affect SWC effort of a household

\begin{tabular}{|c|c|c|}
\hline $\begin{array}{l}\text { Explanatory } \\
\text { Variable }\end{array}$ & Description and Unit of Measurement & $\begin{array}{l}\text { Apriori } \\
\text { Sign }\end{array}$ \\
\hline $\mathrm{X} 1=\mathrm{GENDER}$ & $\begin{array}{l}\text { Gender of the household head: } 1 \text { if the household head is male, } 2 \\
\text { otherwise }\end{array}$ & $+/-$ \\
\hline $\mathrm{X} 2=\mathrm{AGE}$ & Age of the household head (years) reduced to $1-5$ scale & + \\
\hline $\mathrm{X} 3=\mathrm{EDUCATION}$ & Educational level of the household head (years) & + \\
\hline $\mathrm{X} 4=\mathrm{SOCIAL}$ & $\begin{array}{l}\text { Social position of the household head: } 1 \text { if the household head has social } \\
\text { position in the community, } 0 \text { otherwise }\end{array}$ & + \\
\hline X5=FAMILYSIZE & Family size of the household (number) & + \\
\hline X6=AGRILABOR & Agricultural labour of the household (number) & + \\
\hline $\mathrm{X} 7=\mathrm{SLOPE}$ & $\begin{array}{l}\text { Average slope category of household's farm plots: } 1 \text { flat and gentle, } 2 \\
\text { otherwise }\end{array}$ & + \\
\hline $\mathrm{X} 8=\mathrm{OFFFARM}$ & $\begin{array}{l}\text { Off-farm activities, } 1 \text { if household head has off-farm activities, } 0 \\
\text { otherwise }\end{array}$ & $+/-$ \\
\hline X9=LIVESTOCK & Livestock holding of a household in Tropical Livestock Unit & $+/-$ \\
\hline X10=TRAINING & Training in SWC/related area, 1 if household head is trained, 0 otherwise & + \\
\hline X11=TENUREIN & $\begin{array}{l}\text { Perception of household head on the negative effects of tenure insecurity } \\
\text { in SWC effort, } 5=\text { very bad, } 4=\text { bad, } \\
3 \quad=\text { moderate, } \quad 2=\text { little effect, } \quad 1=\text { no effect }\end{array}$ & - \\
\hline
\end{tabular}

\section{Results and Discussion}

\section{Descriptive statistics of the respondents}

Among the surveyed household heads, $27.78 \%$ were women. The average age of the respondent household heads was 55 years, 25 being the lowest and 83 the highest, and their average educational level was grade 4 , never went to school being the lowest and $12^{\text {th }}$ grade the highest. Looking at the educational levels of 
respondents, $23.61 \%$ had no formal education, $44.44 \%$ were elementary school (grade 1-5), 20.83\% were middle school (grade 6-8), and only $11.11 \%$ reached high school (grade 9-12). None of the women respondents had attended high school classes, $65 \%$ of them were elementary school level. Only $4 \%$ of the household heads participated in agriculture related trainings during the last 10 years. Off-farm activities, mainly trade and masonry work constituted $33.33 \%$ of the respondents. The average family size was 7 with a minimum of 2 and maximum of 12 members in a family. The average agricultural labor of households was 4 . The average livestock holding of the households was 3.75 Tropical Livestock Unit (TLU), with 0 minimum and 10 maximum.

According to the criteria set for a threshold SWC effort of a household only $23.61 \%$ of the respondents were found to fulfill it, which indicated that the level of SWC effort of households was very small. The results of group discussions and participatory transect walks revealed that above $90 \%$ of sloppy farmers' fields in Gheshnashm and Shimangus Lailai had old SWC structures, mostly constructed by FFW programmes and mass campaigns. In Basheri area, though SWC activities were weak, stone-walled terraces, permanent earth bunds (Deret), bush barriers, contour ploughing and manure application were the local SWC and soil fertility management practices. The use of crop rotation was low in Basheri, mainly due to crop failures, especially legumes, during short rains. Generally, stone-walled terraces, permanent earth bund (Deret) terraces, stone and earth bunds, fallowing, crop rotation, manure/fertilizer application, contour ploughing and mobile bunds were the common SWC measures that have been practiced with different degrees of use.

\section{Factors that affect SWC effort of a household}

Results of the hypothesized logistic model showed that among the 11 hypothesized explanatory variables, five variables significantly affected SWC effort of a household (at 5\% level of significance). Off-farm activities (OFFFARM), tenure insecurity (TENUREIN), household head being female (GENDER), slope of a farmland (SLOPE) and educational level of household head (EDUCATION), ordered in their decreasing strength, significantly affected SWC efforts of a household. Slope of a farmland showed a positive effect but the other four variables affected SWC effort of a household negatively. Training in SWC, social position, age of household head, family size, agricultural labour and livestock holding of a household didn't show any significant effect on SWC effort of a household.

Farmers prioritized land tenure insecurity as the first most constraint in SWC effort of a household. Their argument was strongly supported by the fact that tenure insecurity showed a significant negative effect on SWC effort of a household in the logistic regression analysis. This implied that farmers have greater incentives for investing in conservation structures if they think that the time of land holding was long enough to justify and reward their investment costs. Thus, a farmer concentrates in short-term coping strategies of production decline, assuming that his/her field was going to be taken by other farmer very soon. These results were consistent with the findings of [16,17 and 21].

Farmers prioritized weak extension service as the second most constraint in SWC effort of a household. This was also supported by the developed model; training in SWC and social position of a household head are related to extension service. If a SWC trained farmer couldn't make better SWC effort than untrained farmer that means the trainings were not effective. This strongly supports the farmers' observations; as they emphasized it, the trainings were theoretical and basic.

Farmers prioritized the unattractiveness and risk-proneness of the agricultural sector as the third most constraint in SWC effort of a household. Farmers tended to look for other alternatives of income to support their family; they acted as part time farmers. This was in line with the results of the regression analysis in which off-farm activities showed significantly negative effect on SWC effort of a household. This finding contradicted with the findings of [5,7] where they reported that off-farm activities generated income and SWC investment were strengthened by that income. However, in this study's case, most of the off-farm activities of the households were meant for subsistence and often take much of household head's time that could have been used for on-farm activities.

Female being a household head showed significantly negative effect on SWC effort, as women are busy with children care, daily home works (like cooking, washing utensils etc), pregnancy time, child delivery etc, they might not had enough time to deal with SWC. Cultural barriers also restrict women from participating in SWC activities. Thus, a woman household head might not influence or manage the family so as to conserve its farmland.

Educational level of a household head had significant negative effect on SWC effort. This agreed with the findings of $[8,17]$. This was due to the fact that educated farmers became more cautious in their investment decisions, without tenure security they may decide not to invest in permanent conservation structures. Moreover, agriculture has not yet transformed to business, it is still in the subsistence stage. Thus, educated people might not want to apply effort in SWC, rather they preferred to look at off-farm activities taking the 
advantages that their education might provide them with job opportunities. On the contrary, reference [9] found that level of education had significant positive effect on SWC effort of a household in Ethiopia.

The positive significance of slope of a farmland to SWC effort of a household illustrated the fact that farmers strengthen their SWC effort if they perceive that there was erosion in their fields. Flat and gentle plots might not show serious erosion signs, even though sheet erosion was common. Sloppy fields might develop rills very shortly due to fast running runoff along slopes; farmers easily identified this and acted to minimize the effects of erosion through SWC measures. This result was in line with the findings of [1,5,9 and 17].

Furthermore, legacy of the past FFW and CFW programmes had cultured farmers to consider SWC as an extra income-generating activity rather than incorporating it to their farming systems. This was strongly supported by [11], where the same results were found in Afdeyu, Eritrea.

Table 2: Coefficient estimates of the logistic regression analysis

\begin{tabular}{|l|c|c|c|c|c|c|}
\hline Variable & B & S. E & Wald & df & Sig. & Exp ( $)$ \\
\hline GENDER & -6.793 & 3.219 & 4.453 & 1 & $0.035^{*}$ & .001 \\
\hline AGE & 0.408 & 0.877 & 0.217 & 1 & 0.642 & 1.504 \\
\hline EDUCATION & -2.443 & 1.240 & 3.881 & 1 & $0.049^{*}$ & .087 \\
\hline SOCIAL & 3.173 & 1.986 & 2.552 & 1 & 0.110 & 23.870 \\
\hline FAMILYSIZE & 0.403 & 0.891 & 0.204 & 1 & 0.652 & 1.496 \\
\hline AGRLABOR & 0.752 & 0.560 & 1.806 & 1 & 0.179 & 2.121 \\
\hline SLOPE & 3.452 & 1.669 & 4.280 & 1 & $0.039^{*}$ & 31.576 \\
\hline OFFFARM & -8.964 & 3.717 & 5.816 & 1 & $0.016^{*}$ & .000 \\
\hline LIVESTOCK & -0.103 & 0.277 & 0.140 & 1 & 0.709 & .902 \\
\hline TRAINING & 4.059 & 2.985 & 1.849 & 1 & 0.174 & 57.932 \\
\hline TENUREIN & -6.190 & 2.684 & 5.319 & 1 & $.021^{*}$ & .002 \\
\hline
\end{tabular}

Where $\beta=$ regression coefficient associated with the variable, $\mathrm{SE}=$ standard error of the regression coefficient, Wald $\mathrm{x}^{2}$ test statistic, * statistically significant at $5 \%$ level

\section{Conclusions}

Throughout Eritrea in general and the highlands and midlands in particular, traditional SWC had been practised since time immemorial. With the advent of European colonial period, additional SWC measures had also been introduced to combat land degradation. However, these interventions had not yielded the desired level of result owing to a number of intermingled factors. Among the 11 independent factors studied, five of them had been identified as being significant. These were: off-farm activities, land tenure insecurity, gender, and slope of the agricultural fields and level of education of a household head. These problems were exacerbated by ineffective and inefficient agricultural extension services which resulted in poor field management and hence low agricultural production.

\section{Recommendations}

Implementation of the land reform proclamation (No.58/1994), which gives a lifelong usufruct right to land holders is vital for the adoption of SWC measures. This could favour farmer's investment decisions towards sustainable land resources use.

The practice of SWC requires a fundamental change in the way farmers perceive and their attitude towards farming so as they consider SWC as a part of their farming system. Massive extension training could play a great role in bringing a radical change in the farmers' knowledge, attitude and perception.

Female headed farmers need to be also empowered through training, provision of material and financial support.

\section{References}

[1]. Akalu, T., J. D. Graaff and S. Leo. (2014). Evaluation of soil and water conservation practices in the north-western Ethiopian highlands using multi-criteria analysis. Frontiers in Environmental Sciences, 2(60).

[2]. Amanuel, N., B. Tengnas, B. Estifanos, and G. Kifle. (2000). Soil and Water Conservation in Eritrea: Some case studies. RELMA. ICRAF House, Gigiri, P.O. Box 63403, Nairobi, Kenya: RELMA .

[3]. Bank, W. (1994). Eritrea: options and strategies for growth, executive summary and main report. Washington.

[4]. Bekele, E. (2003). Causes and consequences of environmental degradation in Ethiopia. In: Gedion, A. (edns.), Environment and environmental change in Ethiopia. Consultation Papers on Environment No. 1., Forum for Social Studies, Addis Ababa. 
[5]. Bereket, A. (1997). The economics of soil conservation in the highlands of Eritrea. MA Thesis, School of Economics, the University of Queensland.

[6]. Bhandrari, P. B. (2003). Participatory Rural Appraisal (PRA). AGES Institute for Global and Environmental Studies.

[7]. Debebe, W., K. Melaku, T. Menfese, and G. Tesfaye. (2013). Farmers' perceptions and participation on mechanical soil and water conservation techniques in KembataTembaro Zone: the Case of Kachabirra Woreda, Ethiopia. International Journal of Advanced Structures and Geotechnical Engineering, 02(04).

[8]. Demeke, B, A. (2003). Factors affecting adoption of soil and water conservation practices in north western Ethiopia. Institute of rural development, University of Gottingen.

[9]. Fikru, A. M. (2009). Assessment of adoption behavior of soil and water conservation practices in the koga watershed, highlands of Ethiopia. MA thesis, Graduate School of Cornell University .

[10]. Gujarati, D. N. (2004). Basic Econometrics (4 ${ }^{\text {th }}$ edition). The McGraw-Hill Companies.

[11]. Gurtner, M., Z. Goitom, E. Henok, Z. Tesfaalem, H. Yonas, S. Brigita and P. Roden. (2006). Land Management in the Central Highlands of Eritrea: A Participatory Appraisal of Conservation Measures and Soils in Afdeyu and its Vicinity. Geographica Bernens.

[12]. Kifle, G. and D. Randcliffe. (1997). Agro-ecological zones of Eritrea. Ministry of Land, Water \& Environment. Asmara, Eritrea.: Ministry of Land, Water \& Environment.

[13]. Kipsat, M. J. (2002). Economic Analysis of the Use of Non-Conventional Fertilizer Technologies in Vihiga District of Western Kenya. M.Sc. Thesis, Moi University, Eldoret, Kenya.

[14]. Neupane, R. P., K. R. Sharma and G. P. Thapa. (2002). Adoption of Agroforestry in the Hills of Nepal: A Logistic Regression Analysis. 72[3], 177-196.

[15]. Okoba, B. O. and J. D. Graaff. (2005). Farmers' knowledge and perceptions of soil erosion and conservation measures in the central highlands, Kenya. 16, 475-487.

[16]. Sabita, G. (2010). The Effect of Rural Land Registration and Certification Programme on Farmers' Investments in Soil Conservation and Land Management in the Central Rift Valley of Ethiopia. Land degradation and development.

[17]. Simon, A., C. A. Shisanya and J. A. Obando. (2012). Analysis of Factors Influencing Adoption of Soil and Water Conservation Technologies in Ngaciuma Sub-Catchment, Kenya. African Journal of Basic \& Applied Sciences, 4 [5], 172-185.

[18]. Stillhardt, B. and L. Frey. (2001). A survey for sustainable development of the Adi Behnuna community, Eritrea. Centre for Development and Environment (CDE).

[19]. Tripathi, R. P., K. Isaac, and O. Woldeselassie. (2015). Tillage and Irrigation Requirements of Sorghum (Sorghum bicolor L.) at Hamelmalo, Anseba Region of Eritrea. Open Journal of Soil Science, 5, 287-298.

[20]. Tumuzghi, T. (2016). Impact Assessment of Soil and Water Conservation Interventions in Hamelmalo and Serejeka Areas, Eritrea. MSc Thesis, Department of Land Resources and Environment, Hamelmalo Agricultural College, Keren Eritrea.

[21]. Zaal, F. (2011). Understanding Adoption of Soil and Water Conservation Techniques: The role of new owners. Centre for the study of African Economies Royal Tropical Institute, Amsterdam AISSR, University of Amsterdam. 